i таким чином здійснити комбінацію складових елементів задля прийняття рішення; здатність до дослідження суперечностей у спостережуваних фактах, зіставлення різних явищ і до виявлення характеру зв'язку між цими явищами.

Узагальнення теоретичних засад дозволили скласти таке уявлення про професіоналізм управління як результат усвідомленої цілеспрямованої діяльності, що передбачає певний рівень професійної компетентності менеджера освіти як керівника освітньої установи.

Управлінська компетентність менеджера освіти - це органічний комплекс загальних і спеціальних знань, умінь, навичок, здібностей, що забезпечують ефективність управління навчальним закладом у сучасних умовах, складається 3 низки компонентів, що зумовлюються функціями менеджера освіти: економічного, планово-прогностичного, стратегічного, організаційного, контролювального, інформаційно-аналітичного.

\title{
Література
}

1. Бондар В. І. Конкурентоздатність педагога як складова його професійної компетентності / В. І. Бондар // Початкова школа. - 2008. - №7. - С. 22-23. 2. Вдовиченко Р. Функціональнопосадові вимоги до професійної управлінської діяльності керівника школи / Р. Вдовиченко // Рідна школа. - 2005. - № 2. - С.16-21. 3. Коломінський Н. Л. Психологія педагогічного менеджменту / Н. Л. Коломинський. - Київ : МАУП, 1996. - 176 с. 4. Коротков Е. Концепція якості освіти / Е. Коротков // Підручник для директора. - 2006. - № 7. - С. 11-14. 5. Прасол Д. Структура прогностичного компонента та його роль в управлінській діяльності / Д. Прасол // Соціальна психологія. - 2005. - № 5 (13). - С. 38-45. 6. Сорочан Т. М. Підготовка керівників шкіл до управлінської діяльності: теорія та практика:[монографія] / Т. М. Сорочан. - Луганськ : Знання, 2005. - 384 с. 7. Тонконога Е. П. Проблемы повышения профессиональной квалификации руководителей школ / Е. П. Тонконога. - М. : Педагогика, 1987. - 236 с. 8. Третьяков П. И. Управление школой по результатам: Практика педагогического менеджмента / П. И. Третьяков. М. : Новая школа, 1997. - 228 с. 8. Фатхутдинов Р. Концепция подготовки специалистов по менеджменту / Р. Фатхутдинов // Высшее образование в России. - 1996. - №4. - С. 31-38. 9. Филиппов А. В. Работа с кадрами: психологический аспект / А. В. Филиппов. - М., 1990. - 255 с.

\section{ФОРМУВАННЯ ФАХОВОЇ КОМПЕТЕНТНОСТІ МАЙБУТНЬОГО ВЧИТЕЛЯ ПОЧАТКОВИХ КЛАСІВ ЗАСОБАМИ ІННОВАЦІЙНИХ ПЕДАГОГІЧНИХ ТЕХНОЛОГІЙ}

Зичков А. К. Формування фахової компетентності майбутнього вчителя початкових класів засобами інноваційних педагогічних технологій.

У статті розглянуто проблеми фахової компетентності як складника інноваційної діяльності майбутнього вчителя початкових класів.

Ключові слова: компетентність, компетенція, педагогічна технологія, інноваційні технології.

Зычков А. К. Формирование профессиональной компетентности будущего учителя начальных классов средствами инновационных педагогических технологий.

В статье рассмотрены проблемы профессиональной компетентности как составляющей инновационной деятельности будущего учителя начальных классов.

Ключевые слова: компетентность, компетенция, педагогическая технология, инновационные технологии.

Zychkov A. K. The formation of the professional competence of the future elementary school teacher by the facilities of innovative pedagogical techniques.

In the article the problems of the professional competence as a component of the innovative activity of the future elementary school teacher are discussed.

Key words: competence, competency, pedagogical technology, innovative techniques. 
Проблема формування фахової компетентності майбутнього вчителя початкових класів засобами інноваційних педагогічних технологій не $\epsilon$ новою. «Компетентність не зводиться лише до накопичення досвіду в певній вузькоспеціальній предметній галузі, - пише Дж. Ровен, - інакше, де проходить межа між компетентністю та «професіональним кретинізмом».

Як слушно зазначає І. Дичківська, інноваційна педагогічна діяльність «заснована на осмисленні практичного педагогічного досвіду цілеспрямована педагогічна діяльність, зорієнтована на зміну й розвиток навчально-виховного процесу задля досягнення вищих результатів, одержання нового знання, формування якісно іншої педагогічної практики» $[1$, c. 248$]$.

На сучасному етапі розвитку педагогічної науки цілі неперервної освіти вчителів початкових класів визначаються соціальними потребами й особистими запитами щодо формування їхньої професійної компетентності, а саме: освіта 3 метою подолання елементарної і функціональної неграмотності; перепідготовка, додаткова підготовка (оволодіння складними професіями, повна перекваліфікація на нові професії); підвищення професійної кваліфікації в межах уже отриманої спеціальності; розширення та збагачення знань у різних галузях культури, науки, соціальної сфери відповідно до особистих інтересів, безпосередньо не пов'язаних із професією.

Проблема визначення професійної компетентності вчителя стала об'єктом дискусій і суперечок серед психологів, педагогів, фізіологів, спеціалістів-практиків тощо. Немає єдиного підходу до визначення поняття «професійна компетентність учителя».

Водночас вітчизняна педагогіка вже має певні напрацювання в цьому напрямку. Проблеми педагогічної інноватики постійно привертають увагу сучасних дослідників. Визначення й обгрунтування основних методологічних $\mathrm{i}$ теоретичних положень інноваційної педагогічної діяльності висвітлено у працях І. Беха, Ю. Гільбуха, C. Гончаренка, I. Дичківської, В. Ковальчук, О. Овчарук, М. Поташник, Г. Селевко, I. Тараненко та інші.

Більшість авторів зіставляють поняття «компетентність» i «професіоналізм». Так, наприклад С. Дружилов визначає, що досягнення професійного успіху пов'язане із забезпеченням необхідного рівня професійної компетентності [2, с. 32].

I. Перестороніна акцентує увагу на тому, що професійна компетентність вчителя становить сукупність професіонально-педагогічних компетенцій:

1) соціально-психологічна компетенція, пов'язана 3 готовністю до розв'язання професіональних задач;

2) комунікативна і професіонально-комунікативна компетенції;

3) загальнопедагогічна професійна компетенція (психолого-педагогічна і методична);

4) предметна компетенція;

5) професіональна самореалізація [7, с. 178].

Під компетенцією розуміється сукупність якостей особистості, а також професійні знання, уміння, навички.

У розробках російських науковців на нашу увагу заслуговують тлумачення А. Маркової та Н. Кузьміної. Так, у своїх дослідженнях А. Маркова характеризує зміст професійної компетентності педагога процесуальними і результативними показниками й визначає професійну компетентність фахівця як здатність та готовність виконувати особисту професійну діяльність [6, с. 31].

Н. Кузьміна розглядає професійно-педагогічну компетентність педагога за фахом i визначає іiі як сукупність умінь педагога як суб'єкта педагогічного впливу особливим способом структурувати наукове і практичне задля найкращого розв'язання педагогічних завдань [5, с. 17].

Meта статmi полягає у розкритті ключових аспектів проблеми формування фахової компетентності майбутнього вчителя початкових класів засобами інноваційних педагогічних технологій. 
У психолого-педагогічній літературі поняття компетентності набуло широкого розповсюдження порівняно недавно. Наприкінці 1960-х - на початку 1970-х років у західній, а в кінці 1980-х р. у вітчизняній літературі зароджується спеціальний напрям компетентнісний підхід в освіті.

Аналіз літератури показує, що автори по-різному підходять до визначення поняття компетентності взагалі та професійної компетентності зокрема.

Уведення кожного нового поняття потребує наукового обгрунтування, уточнення, розробки й тлумачення, зокрема педагогами, якщо це стосується збагачення понятійнотермінологічного апарату педагогіки за рахунок тих чи тих понять, які використовуються в різних зарубіжних системах, у міжнародних угодах, інших документах тощо.

Термін «професійна компетентність» фахівця - одне з найуживаніших нових понять, що виникли в педагогічній науці та освітній практиці нашої країни в останнє десятиріччя.

У наукових текстах поняття «компетентність» перемежовується і часто є замінником традиційного в нашому контексті поняття «кваліфікація».

Найчастіше поняття «компетентність» використовується в таких державних документах, як стандарти підготовки фахівців різних профілів; і передбачає втзначення вимог не лише до викладача, а й до студента.

Водночас до державних документів уводиться поняття «компетенції» (учня, вчителя, фахівця). Скажімо, у Державному стандарті базової повної середньої освіти широко використовується поняття «компетенції учня» (соціальна, комунікативна, літературна, мистецька тощо). Уточнюючи зміст цього поняття, розробники стандартів звертаються до певних його характеристик.

Суттєві перетворення в системі освіти потребують розв'язання проблеми підвищення професійної компетентності вчителя, який уміє визначати й досягати нових педагогічних цілей.

Що стосується терміна «фахова компетентність», то деякі автори визначають його 3 прагматичної точки зору, але більшість - як інтегративну властивість майбутнього вчителя початкових класів.

Проаналізувавши психолого-педагогічні джерела щодо сукупності основних ключових компетентностей, які необхідні особистості в іiі професійній діяльності, ми дійшли висновку, що сучасний учитель початкових класів для реалізації педагогічної діяльності має оволодіти певними групами компетентностей, а саме:

1. Компетентність у професійній сфері:

a) професійна, спрямована на викладацьку діяльність;

б) професійна спрямованість на виховну та розвивальну діяльність;

в) професійна, спрямована на самовдосконалення.

2. Компетентність у комунікативно-соціально-морально-етично-правовій сфері.

3. Компетентність у науковій психолого-педагогічній і культурологічній сфері.

4. Компетентність в інформаційно-технологічній сфері.

5. Компетентність у дослідницько-діагностувальній сфері.

У свою чергу «життєва компетентність - це знання, вміння, життєвий досвід особистості, необхідні для розв'язання життєвих завдань і продуктивного здійснення життя як індивідуального проекту» (І. Срмаков).

Отже, компетентність визначається як спроможність кваліфіковано здійснювати діяльність. Компетентність - це поняття, що логічно перебуває в тісному взаємозв'язку зі ставленням до цінностей та - від умінь до знань.

Виходячи 3 аналізу поняття в наукових джерелах, ми вважаємо, що під фаховою компетентністю майбутнього вчителя слід розуміти інтегральне утворення особистості, яке містить соціально-політичний, професійний, науково-технологічний, дослідницькодіагностувальний, морально-культурологічний та інформаційний компоненти, необхідні для успішного здійснення педагогічної діяльності. 
Сучасний освітянський простір створює всі умови для підготовки вчителя початкових класів засобами інноваційних педагогічних технологій.

Поняття «технології» за словниковим тлумаченням означає (з грецької) techne мистецтво, майстерність, вміння, a logos - вчення, поняття. У педагогіку воно прийшло 3 виробництва, де визначається як сукупність методів оброблення, виготовлення, зміну стану, властивостей, форми сировини, матеріалу, що здійснюється у процесі виробництва продукції. Технологія досягнення одного й того ж результату може змінюватися, вдосконалюватися за рахунок поновлення чи вдосконалення методів.

Єдиного тлумачення поняття «педагогічна технологія» в науці донині не було запропоновано. У широкому значенні технологія - це розроблення певної ідеї.

Наведемо кілька прикладів. І. Лернер визначає технологію педагогічного процесу як сукупність необхідної і відтворюваної послідовності педагогічних дій учителя й учнів, що «запускає» механізм засвоєння змісту освіти і веде до запланованої мети і успішного навчання учнів. У цьому визначенні підкреслюються два аспекти: запланована сукупність певних дій i обов'язковість досягнення мети навчання. Інше тлумачення технології пропонує М. Кларін. Розглядаючи передісторію проблеми, він указує на такі її витоки, як технологізація навчального процесу, програмування навчання i, нарешті, комп'ютеризація (використання нових інформаційних технологій).

На сучасному етапі технологічний підхід у педагогічній науці є пріоритетним майже для всіх країн світу.

Українські науковці, зокрема, В. Паламарчук, С. Рудаківська та інші, розуміють поняття «технологія» навчально-виховного процесу як моделювання його змісту, форм i методів відповідно до поставленої мети.

Тому пошук педагогічних технологій, які б розглядали дитину як головний пріоритет і цінність, як суб'єкт культури і життя, є найбільш актуальним завданням сучасної педагогічної науки і практики. Інтегрування до європейських структур і динамізація економіки посилюють необхідність розв'язку завдань, які б забезпечували ефективне навчання і виховання учнів, підготовку їх до входження в соціум, формування в них таких якостей, які здатні були б вивести державу з кризового стану. Велике значення в реалізації цього підходу відіграють інтерактивні технології навчання (ITH).

Початкова школа нині впроваджує багато інноваційних технологій. Актуальними зпоміж яких $є$ такі групи: технології особистісно зорієнтованого навчання й виховання; традиційні педагогічні технології на основі активізації та інтенсифікації діяльності учнів; педагогічні технології, що розробляються на основі підвищення ефективності управління й організації навчального процесу; педагогічні технології, що розробляються на основі дидактичного вдосконалення та реконструювання матеріалу; окремі предметні педагогічні технології; альтернативні педагогічні технології; педагогічні технології розвивального навчання й педагогічні технології авторських шкіл [3, с. 46].

Отже, педагогічна технологія - це інтегративна модель навчально-виховного процесу 3 чітко визначеними цілями, спроектованими на досягнення мети, діагностикою початкових та кінцевих результатів, розподілу навчального матеріалу на окремі компоненти, чітке та неухильне виконання певних навчальних дій в умовах оперативного зворотного зв'язку.

Отже, фахова компетентність майбутнього вчителя початкових - складний, безперервний, творчий процес його професійної самореалізації. Тому кожен майбутній учитель, який прагне до вдосконалення своєї педагогічної майстерності, повинен усвідомити перспективи свого професійного розвитку у процесі інноваційної педагогічної діяльності.

Результати теоретичного аналізу показують, що проблема професійної підготовки майбутніх учителів початкових класів до впровадження інноваційних технологій у навчальний процес початкової школи є актуальною і потребує подальшого дослідження. 


\section{Література}

1. Дичківська І. М. Інноваційні педагогічні технології : [навч. посіб.] / І. М. Дичківська. - К. : Академвидав, 2004. - 352 с. 2. Дружилов С. А. Обучение и стадии профессиональной компетентности / С. А. Дружилов // Непрерывное образование как условие развития творческой личности. - Новокузнецк : ИПК, 2001. - С. 32-33. 3. Інноваційні пошуки в сучасній освіті / за заг. ред. Л. І. Даніленко, Е. Ф. Паламарчук. - К. : Логос, 2004. - 220 с. 4. Компетентнісний підхід у сучасній освіті: світовий досвід та українські перспективи: [бібліотека з освітньої політики / за заг. ред. О. В. Овчарук]. - К. : «К.І.С.», 2004. - 112 с. 5. Кузьмина Н. В. Акмеология: пути достижения вершин профессионализма / Н. В. Кузьмина. - М. : РАУ, 1993. - 73 с. б. Маркова А. К. Формирование мотивации учения в школьном возрасте : [пособие] / А. К. Маркова. - М. : Просвещение, 1983. - 96 с. 7. Пересторонина И. Л. Особенности формирования профессиональной компетентности будущего учителя при изучении второго иностранного язика / И. Л. Пересторонина // Научное исследование и российское образование: идеи и ценности 21 века: [материалы 6-й междисциплинарной научно-практической конференции аспирантов и соискателей (3-4 апреля 2003 года)] / сост. Н. В. Фанькина. - М. : АПК и ПРО, 2003. - С. 177-181. університету імені Тараса Шевчека

\section{НАВЧАННЯ КУРСАНТІВ ВИЩИХ ВІЙСЬКОВИХ НАВЧАЛЬНИХ ЗАКЛАДІВ ІНШОМОВНОГО ПРОФЕСІЙНО-ОРІЕНТОВАНОГО АУДІЮВАННЯ}

Златніков В.Г. Навчання курсантів вищих військових навчальних закладів іншомовного професійно-орієнтованого аудіювання.

У статті наголошується, що іншомовне спілкування стає важливим елементом професійної діяльності майбутніх офіцерів Збройних сил України; розглядаються особливості навчання курсантів вищих військових навчальних закладів іншомовного професійно-орієнтованого аудіювання. Проаналізовано основні причини, що зумовлюють складність сприймання на слух військової термінології.

Ключові слова: майбутні офіцери, професійно-орієнтоване аудіювання, військова термінологія, емоційно забарвлене мовлення, військова лексика, військовий сленг, нестатутна термінологія.

Златников В.Г. Обучение курсантов высших военных учебных заведений иностранному профессионально-ориентированному аудированию.

В статье подчеркивается роль иноязычного общения в профессиональной деятельности будущих офицеров Вооруженных сил Украины; рассматриваются особенности обучения курсантов высших военных учебных заведений иноязычному профессиональноориентированному аудированию. Проанализированы основные причины сложности восприятия на слух военной терминологии.

Ключевые слова: будущие офицеры, профессионально-ориентированное аудирование, военная терминология, эмоционально окрашенная речь, военная лексика, военный сленг, неуставная терминология.

Zlatnikov V. H. Teaching cadets of higher military educational institutions professionally-oriented listening comprehension.

The paper highlights the role of foreign language communication in the professional activity of the future officers of the Armed Forces of Ukraine; the features of cadets' training of professionally-oriented listening comprehension are considered. The main difficulties of listening comprehension of military terminology are analyzed.

Key words: future officers, listening comprehension, war terms, emotionally coloured speech, soldiers' argot, not according to regulations terminology. 